\title{
The Reality of Using E-Learning Applications in Vocational Education Courses During COVID 19 Crisis from the Vocational Education Teachers' Perceptive in Jordan
}

\author{
Sameer Aowad Kassab Shdaifat ${ }^{1}$, Nidal A. K. Shdaifat ${ }^{1} \&$ Linda Ahmad Khateeb $^{2}$ \\ ${ }^{1}$ Vocational Education Department, Al-Balqa Applied University, Jordan \\ ${ }^{2}$ Faculty of Educational Science, Isra University, Jordan \\ Correspondence: Sameer Aowad Kassab Shdaifat, Vocational Education Department, Al-Balqa Applied \\ University, Jordan.
}

Received: May 5, $2020 \quad$ Accepted: July 1, $2020 \quad$ Online Published: September 21, 2020

doi:10.5539/ies.v13n10p105 URL: https://doi.org/10.5539/ies.v13n10p105

\begin{abstract}
The present study aimed to explore the reality of using E-Learning applications in vocational education courses during COVID 19 crisis in Jordan from the perspective of vocational education teachers. It aimed to explore the way students interact with e-learning applications in this regard. It aimed to explore the challenges associated with using E-Learning applications in this regard. A sample was selected. It consists from 60 vocational education teachers. These teachers were selected from the primary public schools in Jordan. A three-part questionnaire was used. It was found that respondents have negative attitudes towards using E-Learning applications in vocational education courses during COVID 19 crisis in Jordan. It was found that the severity of the challenges associated with using E-Learning applications in this regard is high. In the light of the study's results, several recommendations were proposed. For instance, the researchers recommend providing vocational education teachers at Jordanian schools with training courses about the way of using E-Learning applications.
\end{abstract}

Keywords: e-learning, vocational education, COVID 19

\section{Introduction}

There are many challenges associated with delivering education in public facilities, especially in developing countries. Such challenges include ensuring that all children are provided with education. The severity of such challenges rise when experiencing a crisis (e.g. a political or a healthcare crisis). A global healthcare crisis has been experienced due to the spread of Coronavirus (COVID-19). The spread of this virus led many governments to close educational institutions temporarily-including schools-till resolving the crises.

On 10 March, 2020, UNESCO held a global videoconference through which officials responsible for high education were attending. This videoconference aimed to take measures of emergency in response to the spread of Coronavirus (COVID-19). It aimed to provide those officials with strategies that minimize the negative impacts of such spread on education. UNESCO Institute for Information (IITE) and its global partners in the influenced countries, cooperated with each other to take actions for addressing the negative impacts of such spread on education. They launched an initiative that aims to provide a communication platform for officials, teachers, school students, university students, specialists in education and technology. Through such a platform, those people shall share their experiences with one another and provide each other with recommendations and technical support (Zhan, 2020).

Due to the spread of the Coronavirus, universities in China were closed temporarily. Thus, students started to learn virtually instead of coming to class.. After having this experience, some scholars suggest that the virtual learning environment may become the dominant learning environment in the future (Lau et al, 2020).

In Jordan, the Jordanian government closed schools temporarily to prevent this virus from spreading. Thus, the Jordanian Ministry of Education took measures of emergency in response to the spread of this virus in the world. For instance, after closing schools temporarily, the lessons of school students were broadcasted through a TV channel. That begins on 22-2-2020. The Jordanian Ministry of Education and the Jordanian Ministry of Digital Economy and Entrepreneurship were held responsible for managing the learning process. 
Edraak, Jo Academy and Abwab were responsible for the content being broadcasted. The ministry of education broadcasted lessons for all subjects and grades. It broadcasted lessons based on a weekly schedule. The lessons were broadcasted in Jordan through an online platform too. The students can enter this platform and browse it between 6 AM and 4 PM (World Bank, 2020).

Today, learners worldwide are in need for improving virtual and conventional learning. Policymakers, experts and practitioners suggest that there is a need for improving the quality of the delivered vocational and technical education (VTE). That is needed for meeting the demands of the labor market and people's needs (Brolpito et al., 2016).

Aliyu (2012) suggests that vocational and technical education (VTE) plays a significant role in developing manpower. Therefore, many governments provide much attention to VTE and seek developing it. Providing such attention shall fight against poverty and develop the skills of the manpower.

In order to improve the quality of VTE, e-learning platforms must be used for delivering such education. In addition, attention must be provided to such use.

The methods used for delivering distance-learning can be used for providing people with education and training at convenient times, accessible places, and low costs. However, distance learning mustn't replace conventional learning. In fact, it complements the conventional learning. That shall ensure that learners are not isolated. The social framework for training needs to be adapted to these new forms of training (UNESCO and ILO, 2002).

Vocational education and training (VET) has been facing many challenges. The need for delivering VET has increased. That is attributed to the need for meeting the demands of the labor market and the needs of society. It is attributed to experiencing demographic and economic changes.

E-learning has been seen as an effective way for improving the quality of the education delivered through VET schools. There is a debate among scholars about the advantages and disadvantages of e-learning in such schools. Besides, some studies recently reported a decline in the outcomes gained from e-learning (Belaya, 2018). Arh et al. (2009) found that investment in computers and Vocational Education and Training (VET) is needed. They found that VET teachers lacked the skills requires for using ICTs in daily teaching. They found that those teachers do not have the required motivation. They found that there are barriers to the use of ICT by VET in teaching. Such barriers include: the poor competence of teachers and the inadequacy of the e-learning material. They include: the high cost of infrastructure.

The delivering of e-learning is associated with several problems and challenges. These challenges include technical, didactic and organizational challenges (Ghetto, 2013). There is also a need for designing e-learning material (Fleming et al., 2017).

Due to the significance of vocational education in primary schools, the researchers aimed to explore the reality of using E-Learning applications in vocational education courses during COVID 19 crisis in Jordan from the perspective of vocational education teachers

\subsection{Statement of the Problem and the Study's Questions}

The technical and vocational education and training (TVET) of high quality expands one knowledge and skills. However, delivering it requires recruiting skills of excellent technical, occupational and professional skills. There is a need for having well-developed national TVET systems in order to expand the knowledge of the workforce and develop their skills. That shall enable the workforce to become flexible and responsive. It shall enable the workforce to meet the demands of the labor market (UNESCO and ILO, 2002).

During recent decades, e-learning has been receiving much attention. That applies to e-learning in school and higher education facilities. It has been receiving much attention for delivering vocational education (Gros \& Garcia, 2016).

The use of new media in VET offers great opportunities in terms of improving the quality of education and reducing costs, but presents major challenges to all stakeholders (Belaya, 2018). In the light of the aforementioned information, the present study aimed to explore the reality of using E-Learning applications in vocational education courses during COVID 19 crisis in Jordan from the perspective of vocational education teachers. To be specific, it aimed to answer the following questions:

Q.1. What is the reality of using E-Learning applications in vocational education courses during COVID 19 crisis in Jordan from the perspective of vocational education teachers?

Q.2. How do students interact with E-Learning applications in vocational education courses during COVID 19 crisis in Jordan from the perspective of vocational education teachers? 
Q.3. What are the challenges associated with using E-Learning applications in vocational education courses during COVID 19 crisis in Jordan from the perspective of vocational education teachers?

\subsection{The Study's Objectives}

The present study aimed to explore the reality of using E-Learning applications in vocational education courses during COVID 19 crisis in Jordan from the perspective of vocational education teachers. It aimed to explore the way students interact with e-learning applications in this regard. It aimed to explore the challenges associated with using E-Learning applications in this regard.

\subsection{The Study's Significance}

The present study is significant due to the following reasons:

The present study aimed to shed a light on the reality of using e-learning application for teaching vocational courses to primary school students. It aimed to shed a light on that due to the increasing implementation of distance learning plans by many countries for fighting against the spread of Coronavirus. In response to this virus, many countries were obliged to implement such plans to ensure that school students are provided with education, though schools are closed temporarily. It's very important to assess the effectiveness of the e-education in teaching many courses, including the vocational education course.

The researchers of the present study offer suggestions and recommendations for improving the quality of the delivered VE in primary schools in Jordan during the Coronavirus crisis.

\subsection{Definition of Terms}

The definition of the study's terms is displayed below:

E-Learning: It refers to using technologies for providing students with learning opportunities. Such learning is flexible. It may be defined as the use of information and communication technologies (ICTs) to deliver education to individuals and groups, and improve the way of managing the learning process (Gutierrez et al., 2017).

Vocational education (VE): It refers to the education that aims at developing students' life skills in various areas; (household, tourism, hotels, engineering, maintenance, agriculture, environment, economy, technology, healthcare and safety (Mahasneh \& Al-Azmi, 2015).

Vocational education (VE) teacher: It refers to the teacher who has been developed in scientific, vocational, and knowledge-related areas. This teacher is responsible for delivering vocational education. He/she is responsible for guiding learners in the learning process. He/she serves as a facilitator for the acquisition of knowledge. He/she teaches students how to learn and think (Khames \& Hammud, 2018).

\subsection{The Study's Limits}

The study's limits are presented below:

Spatial limits: The present study targets the public primary schools in Jordan

Temporal limits: The present study was conducted during (January, 2020 -March, 2020)

Human limits: The present study targets the VE teachers working at public primary schools in Jordan

\subsection{Previous Studies}

Belaya (2018) aimed to explore the effects of e-learning in VET. He reviewed the relevant literature that sheds a light on the pros and cons of VET. Based on such a review, it was found that e-learning is beneficial for learners. Belaya (2018) suggests that maximizing the pros associated with e-learning, an online learning approach must be combined with face-to-face learning approach.

Gutierrez et al. (2017) aimed to shed a light on the use of an e-learning platform for delivering vocational education. They reported that 128 participants attended the VET course through the e-learning platform. It was found that the increased number of participants doesn't affect the budget. It was found that e-learning enables instructors to manage the learning process in a better. It was found that e-learning enables motivates students. It was found that all the learning activities were carried out effectively through using the e-learning platform. It was found that the use of an e-learning platform is associated with positive feedback and education of high quality.

Azmi et al. (2017) proposed an m-learning model for delivering Technical and Vocational Education and Training (TVET) to students in Malaysia. The model was developed for meeting the user's requirements in three areas; device, user and social technology. The proposed model shall be used as a guideline in the development of m-learning application. This model enhances the quality of the provided education. It motivates students to learn and makes them interested in the learning process. The latter researchers suggest that m-learning has positive 
impacts on TVET. In fact, TVET through m-learning provides learners with more jobs. It makes learners capable of meeting the demands of the labor market. It enables learners to save time and promote a student-centered learning.

Brolpito et al. (2016) aimed to shed a light on the policies and practices of the digital and online learning (DOL) in vocational education and training (VET) course in Serbia. The study's data-was collected through making field visits to eight secondary VET (SVET) schools in major cities located in Serbia. The latter researchers found that all the selected schools have their own website. However, the websites differ from one to another in terms of the form and the function delivered through the website (Brolpito et al., 2016).

In the websites, there are sections for teachers and students. These sections are used for delivering online learning through using online learning management platforms. The latter researchers found that schools have reliable and regular funding mechanisms for the maintenance, renewal and upgrading the equipment of the digital and online learning (DOL). However, it's still challenging for all the selected institutions to provide maintenance, renewal and upgrading to the latter equipment (Brolpito et al., 2016).

The latter researchers found that most of the selected schools lack an administrative personnel capable of managing the way of using the equipment of the digital and online learning (DOL). Most of the sampled teachers and students suggest that they use e-materials quite rarely. The respondents suggest that the available e-materials are very beneficial and useful.

Mazgon et al. (2015) aimed to shed a light on the problems related to the use of ICT in vocational education and training in Slovenia. It was found that e-material improves the learning strategies adopted by students. Such material enriches students' knowledge. The use of ICT shall positively affect the vocational education and training.

Aliyu (2012) reviewed the literature that is related to the adoption of an e-learning approach for delivering Technical and Vocational Education (TVE). He reviewed the literature that is related to the benefits and challenges facing such adoption. It was found that e-learning is useful for any TVE program. Thus, the latter researcher recommends adopting $n$ e-learning approach for delivering TVE.

Arh et al. (2009) adopts an approach for developing the quality of the Vocational Educational and Training (VET). They suggest that adopting an e-learning approach shall improve the quality of VET. They suggest that adopting an e-learning approach shall promote collaboration among teachers.

\subsection{Comments on the Aforementioned Studies}

Based on the aforementioned studies, e-learning is very important, due to its numerous merits. For instance, an e-learning approach is more effective and less costly than other learning approaches. Several studies shed a light on e-learning. Such studies include: the ones conducted by Lau et al. (2020); Mazgon et al. (2015).

Several studies shed a light on adopting an e-learning approach for delivering vocational education and the challenges associated with that. Such studies include: the ones conducted by Belaya (2018); Gutierrez et al. (2017); Azmi et al. (2017); Brolpito et al. (2016)

Some studies adopted a descriptive analytical approach and used a questionnaire. Other studies collected data through reviewing the literature. Such studies include: the ones conducted by Gutierrez et al. (2017) Azmi et al. (2017) Arh et al. (2009)

Contrary to the aforementioned studies, the present study aimed to explore the reality of using E-Learning applications in vocational education courses during COVID 19 crisis in Jordan from the perspective of vocational education teachers.

\section{Methodology}

\subsection{The Study's Approach}

The researchers adopted a descriptive analytical approach.

\subsection{The Study's Population}

The study's population consists from all the VE teachers who work at public primary schools in Jordan.

\subsection{The Study's Sample}

The study's sample consists from 60 VE teachers who work at public primary schools in Jordan. Those teachers were selected from the schools located in Amman and Zarqa in Jordan. They were selected through using the random sampling method. 


\subsection{The Study's Instrument}

The present study aimed to explore the reality of using E-Learning applications in vocational education courses during COVID 19 crisis in Jordan from the perspective of vocational education teachers. The researchers developed a three-part questionnaire. The first part includes 7 statements. It sheds a light on the reality of using E-Learning applications in vocational education courses during COVID 19 crisis in Jordan. The second part includes 7 statements. It sheds a light on the way the students interacted with E-Learning applications in vocational education courses during COVID 19 crisis in Jordan from the perspective of vocational education teachers. The third part includes 7 statements. It sheds a light on the challenges facing the use of E-Learning applications in vocational education courses during COVID 19 crisis in Jordan. The five point Likert scale was adopted. This scale consists from the following categories: strongly agree, agree, moderate, disagree and strongly disagree. These categories represent the following scores: 5, 4, 3, 2, and 1 .

\subsection{Validity of the Instrument}

The validity of the instrument was measured through passing the questionnaire to several experts in order for them to assess it. Changes were made to the questionnaire in the light of the opinions provided by those experts.

\subsection{The reliability of the Instrument}

The reliability of the questionnaire was measured through calculating Cronbach alpha coefficient. The total Cronbach alpha coefficient value is 0.801 .

\subsection{Methods for Statistical Analysis}

The researchers used the SPSS program in order to meet the study's goals. They used the followings statistical methods:

Frequencies and percentages were calculated to identify the respondents' characteristics

Means and standard deviations were calculated to identify the attitudes of the respondents

Cronbach alpha coefficient values were calculated to measure the reliability of the questionnaire

\subsection{Statistical Criteria for Classifying Means}

2.34 or more: High

1.67-2.34: Moderate

1.67 or less: Low

\section{Results}

\subsection{Results Related to the Study's First Question}

Q.1. What is the reality of using E-Learning applications in vocational education courses during COVID 19 crisis in Jordan from the perspective of vocational education teachers?

To answer this question, means and standard deviations were calculated. These values are presented in Table 1 below.

Table 1 . The reality of using e-Learning applications in vocational education courses during COVID 19 crisis in Jordan from the perspective of vocational education teachers

\begin{tabular}{|c|c|c|c|c|c|}
\hline No. & Statement & Std. & Mean & Rank & Level \\
\hline 3 & The e-learning approach is adopted professionally by teachers & 0.81 & 1.66 & 1 & Low \\
\hline 5 & $\begin{array}{l}\text { The vocational education course is considered an essential } \\
\text { subject on the e-learning platform }\end{array}$ & 0.68 & 1.65 & 2 & Low \\
\hline 2 & $\begin{array}{l}\text { Teachers teach students in a professional manner on the } \\
\text { e-learning learning platform }\end{array}$ & 0.70 & 1.62 & 3 & Low \\
\hline 1 & $\begin{array}{l}\text { Adequate online space is dedicated for VE teachers on the } \\
\text { e-learning learning platform }\end{array}$ & 0.40 & 1.60 & 4 & Low \\
\hline 4 & $\begin{array}{l}\text { Several methods are used for adopting an e-learning learning } \\
\text { approach (i.e. TV, Internet, WhatsApp and etc..). }\end{array}$ & 0.87 & 1.58 & 5 & Low \\
\hline 6 & E-learning applications are easy to use & 0.85 & 1.57 & 6 & Low \\
\hline 7 & E-learning is effective like face to face learning & 0.72 & 1.55 & 7 & Low \\
\hline & Total & 0.91 & 1.61 & \multicolumn{2}{|c|}{ Low } \\
\hline
\end{tabular}


Based on Table 1, it was found that respondents have negative attitudes towards using E-Learning applications in vocational education courses during COVID 19 crisis in Jordan. That is because the total mean is 1.61 and the total standard deviation is 0.91 . The latter mean is low.

The mean of statement (3) is 1.66 which is low. The latter statement states the following: (The e-learning approach is adopted professionally by teachers). The mean of statement (7) is 1.55 which is low. The latter statement states the following: (E-learning is effective like face to face learning).

The latter result may be attributed to the fact that the e-learning approach is recently adopted by Jordanian public and private schools in Jordan. It may be attributed to the fact that decision makers focus on teaching math, Arabic language, English language and science in the e-learning approach rather than focusing on VE courses. The latter result is consistent with the result concluded by Gutierrez et al. (2017).

\subsection{Results Related to the Study's Second Question}

Q.2. How do students interact with E-Learning applications in vocational education courses during COVID 19 crisis in Jordan from the perspective of vocational education teachers?

To answer this question, means and standard deviations were calculated. These values are presented in Table 2 below.

Table 2. The way students interact with e-Learning applications in vocational education courses during COVID 19 crisis in Jordan from the perspective of vocational education teachers

\begin{tabular}{|c|c|c|c|c|c|}
\hline No. & Statement & Std. & Mean & Rank & Level \\
\hline 11 & Students interact much with e-learning platforms & 0.81 & 1.66 & 1 & Low \\
\hline 9 & $\begin{array}{c}\text { Students are keen on receiving VE through an e-learning } \\
\text { platform }\end{array}$ & 0.83 & 1.63 & 2 & Low \\
\hline 14 & $\begin{array}{l}\text { Students are contacted by phone to ensure that they are using } \\
\text { the e-learning platform }\end{array}$ & 0.87 & 1.61 & 3 & Low \\
\hline 10 & $\begin{array}{l}\text { Students play a major role in making the e-learning process } \\
\text { successful }\end{array}$ & 0.86 & 1.59 & 4 & Low \\
\hline 13 & There are incentives for the use of e-learning by students & 0.81 & 1.58 & 5 & Low \\
\hline 15 & Students would like to keep using the e-learning platform & 0.80 & 1.51 & 6 & Low \\
\hline \multirow[t]{2}{*}{8} & $\begin{array}{l}\text { The lesson is easily understood by students when using the } \\
\text { e-learning platform }\end{array}$ & 0.83 & 1.49 & 7 & Low \\
\hline & Total & 0.98 & 1.59 & \multicolumn{2}{|c|}{ Low } \\
\hline
\end{tabular}

Based on Table 2, students' interaction with the e-Learning with the e-Learning applications in vocational education courses during COVID 19 crisis in Jordan is poor from the perspective of vocational education teachers. That's because the total mean is 1.59 which is low.

The mean of statement (3) is 1.66 which is low. It's ranked first. The latter statement states the following: (Students interact much with e-learning platforms). The mean of statement (8) is 1.49 , which is low. It's ranked last. The latter statement states the following: (The lesson is easily understood by students when using the e-learning platform).

The latter result may be attributed to the fact that the e-learning approach is recently adopted by the Jordanian Ministry of Education. Thus, students are not used to adopting this approach. Therefore, they need more time to get used to adopting this approach. It was found that students focus on other courses more than focusing on the VE course. The latter result is consistent with the result concluded by Mazgon et al. (2015).

\subsection{Results Related to the Third Question}

Q.3. What are the challenges associated with using E-Learning applications in vocational education courses during COVID 19 crisis in Jordan from the perspective of vocational education teachers?

To answer this question, means and standard deviations were calculated. These values are presented in Table 3 below. 
Table 3. The challenges associated with using e-Learning applications in vocational education courses during COVID 19 crisis in Jordan from the perspective of vocational education teachers

\begin{tabular}{|c|c|c|c|c|c|}
\hline No. & Statement & Std. & Mean & Rank & Level \\
\hline 18 & $\begin{array}{l}\text { Some e-learning platform must be used at an inappropriate } \\
\text { time }\end{array}$ & 0.96 & 3.81 & 1 & High \\
\hline 21 & $\begin{array}{l}\text { Students' families can't keep tracking students when using the } \\
\text { e-learning platform }\end{array}$ & 0.93 & 3.78 & 2 & High \\
\hline 16 & $\begin{array}{l}\text { To use the e-learning platform, students are in need for having } \\
\text { several smart devices }\end{array}$ & 0.99 & 3.77 & 3 & High \\
\hline 15 & $\begin{array}{l}\text { Teachers aren't capable of taking the individual differences } \\
\text { between students into consideration when using the } \\
\text { e-learning platform }\end{array}$ & 0.91 & 3.74 & 4 & High \\
\hline 17 & $\begin{array}{l}\text { There are additional costs incurred by the teacher and the } \\
\text { student }\end{array}$ & 0.91 & 3.72 & 5 & High \\
\hline 20 & $\begin{array}{l}\text { Teachers find it difficult to assess students' academic } \\
\text { achievement level when using the e-learning platform }\end{array}$ & 0.90 & 3.69 & 6 & High \\
\hline 19 & $\begin{array}{l}\text { There isn't much interaction when using the e-learning } \\
\text { platform }\end{array}$ & 0.93 & 3.68 & 7 & High \\
\hline & Total & 0.97 & 3.75 & \multicolumn{2}{|c|}{ High } \\
\hline
\end{tabular}

It was found that the severity of the challenges associated with using E-learning applications in VE course is high. That is because the total mean is 3.75 .

The mean of statement (18) is 3.81, which is low. It's ranked first. The latter statement states the following: (Some e-learning platform must be used at an inappropriate time). The mean of statement (19) is 3.68, which is low. It's ranked last. The latter statement states the following: (There isn't much interaction when using the e-learning platform).

The latter result may be attributed to the fact that there are many challenges facing students and teachers while using an e-learning platform during the Coronavirus crisis. In addition, the nature of VE courses requires practical application. Such practical applications require having face to face interaction between the students and the teachers. In addition, in many cases, the required academic material isn't available to students. That is attributed to the students' poor financial situation or the incapability of the parent to provide the students with the resources required for the VE course due to the curfew. The latter result is consistent with the result concluded by Belaya (2018) and Brolpito et al. (2016).

\section{Recommendations}

In the light of the aforementioned results, the researchers recommend the following:

Providing vocational education teachers at Jordanian schools with training courses about the way of using E-learning applications.

Making decisions for addressing the challenges associated with using E-learning applications in vocational education courses

Developing policies by the Jordanian Ministry of Education about the way of handling any crisis.

Providing teaches in Jordan with training courses about the teaching methods used for delivering distance education. That shall enable those teachers to deliver distance education of high quality during any potential crisis.

Making reforms to the IT infrastructure in Jordan. That shall enable the Ministry of Education to deliver distance education of high quality during any potential crisis.

\section{Acknowledgments}

The researchers would like to thank the Jordanian Ministry of Education.

\section{References}

Aliyu, M. (2012). Integrating e-Learning in Technical and Vocational Education: A Technical Review. International Journal of Academic Research in Business and Social Sciences, 2(5), 52.

Arh, T., Pipan, M., Blažič, B. J., Debevc, M., \& Peternel, M. M. (2009). Enhancing the E-learning in Vocational 
Education and Training with "VET Community Portal". Recent Advances in E-Activities, Information Security and Privacy, 99, 104.

Azmi, S., Noor, S., \& Mohamed, H. (2017). A Proposed Model Of M-Learning For Technical And Vocational Education Training (Tvet) Students. Journal of Theoretical and Applied Information Technology, 95(12).

Belaya, V. (2018). The Use of e-Learning in Vocational Education and Training (VET): Systematization of Existing Theoretical Approaches. Journal of Education and Learning, 7(5), 92-101. https://doi.org/10.5539/jel.v7n5p92

Brolpito, A., Lightfoot, M., Radišic, J., \& Šcepanovic, D. (2016). Digital and Online Learning in Vocational Education and Training in Serbia: A Case Study. European Training Foundation.

Fleming, J., Becker, K., \& Newton, C. (2017). Factors for successful e-learning: Does age matter? Education + Training, 59(1), 76-89. https://doi.org/10.1108/ET-07-2015-0057

Getto, B. (2013). Anreize für E-Learning. Eine Untersuchung zur nachhaltigen Verankerung von Lerninnovationen an Hochschulen. Universität Duisburg-Essen, Dissertation.

Gros, B., \& García, F.J. (2016).Future Trends in the Design Strategies and Technological Affordances of E-Learning. In M. Spector, B. Lockee, \& M. Childress (Eds.), Learning, Design, and Technology. Springer, Cham. https://doi.org/10.1007/978-3-319-17727-4_67-1

Gutiérrez, I., Sánchez, M. M., Castañeda, L., \& Prendes, P. (2017). Learning e-Learning skills for vocational training using e-Learning: The experience pilonting the (e) VET2EDU project course. International Journal of Information and Education Technology, 7(4), 301. https://doi.org/10.18178/ijiet.2017.7.4.885

Khames, F., \& Hammud, H. (2018). The Reality of Teaching Prevocational Education Course in Primary Education from the Viewpoint of Teachers and Secretaries. Journal of Educational Science Studies, 42(2).

Lau, J., Yang, B., \& Dasgupta, R. (2020). Will the coronavirus make online education go viral. Times Higher Education. Retrieved from https://www.timeshighereducation.com/features/will-coronavirus-make-onlineeducation-go-viral\#survey-answer

Mahasneh, O., \& Al-Azmi, A. (2015). The Effect of Using the Workshop Conversation Approach with the Five-Student Groups in Achievement of Tenth Grade Students in Prevocational Education. Journal of Educational Science Studies, 42(1). https://doi.org/10.12816/0017333

Mažgon, J., Šebart, M. K., \& Štefanc, D. (2015). The Role and Use of E-Materials in Vocational Education and Training: The Case of Slovenia. Turkish Online Journal of Educational Technology-TOJET, 14(4), 157-164.

UNESCO and ILO. (2002). Technical and vocational education and training for the twenty first century. Retrieved from https://www.oas.org/cotep/GetAttach.aspx?lang=en\&cId=569\&aid=836

World Bank. (2020). How countries are using edtech (including online learning, radio, television, texting) to support access to remote learning during the COVID-19 pandemic. World Bank report. Retrieved from https://www.worldbank.org/en/topic/edutech/brief/

Zhan, T. (2020). Combat COVID-19: Keep learning. Together we are on the move! UNESCO Institute for Information Technologies in Education.

\section{Copyrights}

Copyright for this article is retained by the author(s), with first publication rights granted to the journal.

This is an open-access article distributed under the terms and conditions of the Creative Commons Attribution license (http://creativecommons.org/licenses/by/4.0/). 